\title{
Disaster Awareness and Level of Compliance to Disaster Programs in a Highly Urbanized City
}

\author{
John Mark R. Asio ${ }^{1 *}$
}

${ }^{1}$ Gordon College, PHILIPPINES

*Corresponding Author: asio.johnmark@gmail.com

Citation: Asio, J. M. R. (2021). Disaster Awareness and Level of Compliance to Disaster Programs in a Highly Urbanized City. Aquademia, 5(1), ep21003. https://doi.org/10.21601/aquademia/9581

ARTICLE INFO

Received: 5 Aug. 2020

Accepted: 27 Oct. 2020

\begin{abstract}
Disaster is an event that shapes our future. During a disaster, it affects lives, infrastructures, livestock and produce, and we can only adapt to it. The aim of this study is to analyze disaster awareness and level of compliance to disaster programs of selected individuals in a highly urbanized city in Central Luzon, Philippines. The study made use of a descriptive-correlational design. One hundred five (105) individuals took part in the survey using a convenience-sampling technique. This study used an adapted and modified instrument for the survey. For the statistical treatment, the researcher used SPSS 20 in computing the data gathered. Results show that the respondents are aware of disaster but in terms of level of compliance, they answered moderately complied. In addition, there are significant differences in disaster awareness and level of compliance with disaster programs when grouped according to location and the number of family members. Last, there is a relationship between the locations, disaster awareness and compliance level on disaster programs in the study. Based on the results of the study, the researcher recommended pertinent ideas and concepts for improved compliance with disaster programs.
\end{abstract}

Keywords: disaster awareness, level of compliance, disaster programs, highly urbanized city

\section{INTRODUCTION}

The Philippines is a country plagued by different disasters. One can attest that they may have experienced some of the worst disasters the history can ever have. Based on the geographical location, large bodies of water surround the country. The Pacific ring of fire also complicates the islands since most have a history of volcanic eruptions from the previous decades. Typhoons, floods, earthquakes, landslides, drought, and other forms of disasters or calamity batter the country. A disaster-resilient community should be at hand to prevent loss of life, damage to households, and other pertinent investment for human survival. Fakhruddin et al., (2019) showed that disaster risk depends on both physical vulnerability and a wide range of social, economic, and environmental aspects. Thus, we need to consider a sound practice of local disaster risk reduction (Amaratunga et al., 2018).

In an urbanized concept, lives and infrastructures are at stake. Sardi et al., (2019) provided new insight into testing urban resilience and developing a social resilience strategy for reducing disaster risk. However, in reality, for a developing country, this is a great challenge and task to consider. Studies like Heidari et al. (2016), Cubelos et al. (2019), and Valibeigi et al. (2019) focused on urban disaster awareness to improve public participation and disaster resiliency. There are already frameworks for financial resource mobilization (Havko et al., 2017; Kousky \& Shabman, 2017) and measures to summarize the important hazard-resilient buildings (Amaratunga et al., 2018; Chmutina et al., 2018). Socio-economic, political, and cultural conditions hamper the compliance (Ahmed et al., 2018).

Compliance is an important aspect of having a successful transition of a plan in management. Grady et al., (2016) identified barriers to the implementation of disaster risk reduction. Depending on the situation at hand, the urban community must set up a concrete plan of action when a disaster strikes. Household preparation levels should be good (Tam et al., 2018) in the city since it has the resources for human survival. Dwirahmadi et al. (2019) showed that stakeholder groups share common views regarding the important human aspects being central to resilience-building efforts. In relation, Amaratunga et al. (2018) identified needs and skills, which are necessary to produce broader knowledge gaps. Preparation for a disaster is inevitable and stocking up necessary things is essential but needs to be adjusted from time to time (Sudo et al., 2019) those companies in urban areas. 
It is also essential to note that in a study by Seol-a and Sang-il in 2019; they divulged that current workers for the disaster prevention department are insufficient and they assign an excessive number of residents per worker at disaster department. This is a revelation for everyone in the government wherein, help is always along the way when a disaster is ravaging a community least to say, an urban community. The loss of lives is unthinkable and unaccountable. Thus, the government need not overlook this matter. Consequently, Alarslan (2018) concluded that there are still many hard works needed with a view to building better cooperation among different institutions.

In the local scene, Mendoza et al. (2016) mentioned that before the institutionalization of DRRMC, there are activities on disaster preparation and climate change adaptation being conducted as Santos (2020) found that early delivery of warning affects the alertness of the residents and deemed effective by most residents. However, the lack of a comprehensive plan limits the implementation of wide range initiatives on DRRM. Also, Panganiban (2019) explored the citizen satisfaction survey to the quality of service delivery of local government units and identified key factors that influence the satisfaction of users of government services. Conversely, Raza (2018) explained that adaptive and coping capacities of local government units remain very weak and assessment on risk and incorporating it in developing local risk-sensitive physical and development plans are still not part of the planners and decision-makers' agenda.

This study aimed to analyze the disaster awareness and level of compliance on disaster programs of individuals living in a highly urbanized city. The researcher deems the analysis important to the locality since it is also prone to flooding, landslides, earthquakes, tsunami, typhoons, and even health and related disasters. The local government can benefit much from the result. It can also shed light on some important details that they might overlook from time to time before, during, and after a disaster strike.

The result is beneficial to the community at the same time to the local government to counteract the results of a disaster. Also, to increase the awareness and compliance of those individuals who dwell in the urban area. And to invoke a disaster-resilient urban community in the far future.

\section{METHOLOGY}

\section{Design}

The study used a descriptive design with a survey as a means of gathering data. According to Creswell and Creswell (2018), the survey provides a quantitative description of trends, attitudes, and opinions of a population, or tests for associations among variables of a population, by studying a sample of that population.

\section{Participants}

One hundred five (105) respondents took part in the survey. The researcher used a convenience sampling technique to gather a sample of the population. According to Creswell and Creswell (2018), the convenience sampling technique is a
Table 1. Profile of the Respondents

\begin{tabular}{llcc}
\hline & Frequency & Percentage \\
\hline Location & 50 & \\
& Upper Land & 55 & 58 \\
& Lower Land & & 52 \\
\hline Sex & Male & 37 & 35 \\
& Female & 68 & 65 \\
\hline Age & 18-30 years old & 34 & \\
& 31-40 years old & 24 & 32 \\
& 41-50 years old & 25 & 23 \\
& 51 years old above & 22 & 24 \\
\hline Members of the Household & & 21 \\
& 1-3 & 31 & \\
& 4-6 & 62 & 30 \\
& 7-10 & 12 & 59 \\
Total & & 105 & 11 \\
\hline
\end{tabular}

nonprobability type of sampling wherein the investigators chose respondents based on their convenience and availability. The respondents were bona fide residents of the target city and have been living for at least 5 years either in the suburb or in the highland areas.

\section{Research Instrument}

This study adapted and modified a survey questionnaire using the REACH Initiative (2015), a research NGO based on Geneva as a guide together with another comprehensive review of related literature. The researcher first tried the questionnaire to 30 individuals who were not part of the study. The use of the pretest-posttest method and Alpha Cronbach test of internal validity established the reliability of the instrument. It yielded an overall coefficient score of .978 which is better than the benchmark score of .70. To check for reliability, the researcher also subjected the questionnaire to any misunderstood words, phrases, or terms for clarification. This study also used a four-point Likert scale for the responses of the surveyed individuals.

\section{Statistical Treatment}

The researcher used several statistical treatments to examine the disaster awareness and level of compliance with disaster programs of the respondents. They include frequency count, percentage, weighted mean, t-test, ANOVA, and Pearson-r. After gathering data, the researcher tallied, tabulated, classified, analyzed, and interpreted the information. The Statistical Package for Social Sciences (SPSS) 20 calculated the statistical treatment of the data. An informal interview follows to validate some inconsistencies on the respondent's answers and clarifies some misconceptions and ambiguity to their answers.

\section{RESULTS}

The study aims to analyze the disaster awareness and level of compliance on disaster programs in a highly urbanized city. The researcher obtained the following results:

Table 1 shows the profile of the respondents who took part in the survey. As seen, there are more respondents in the lower land than in the upper land in terms of location. There are also 
Table 2. Disaster Awareness of the Respondents

\begin{tabular}{|c|c|c|}
\hline Indicators & WM & Interpretation \\
\hline 1) Awareness of the different kinds/types of disasters & 2.56 & Aware \\
\hline 2) Familiarity of the types of disasters (storm, earthquake, tsunami, diseases, etc.) & 2.83 & Aware \\
\hline 3) The main causes of disasters (nature, God, climate, deforestation, poverty, etc.) & 2.92 & Aware \\
\hline 4) The main causes of disasters affect the area you are living in & 2.52 & Aware \\
\hline 5) Existence of a Risk reduction priority in the area & 1.93 & Moderately Aware \\
\hline Average & 2.71 & Aware \\
\hline
\end{tabular}

*Legend: 1.00-1.49=Not Aware; 1.50-2.49=Moderately Aware; 2.50-3.49=Aware; 3.50-4.00=Very Much Aware

Table 3. Level of Compliance on Disaster Programs

\begin{tabular}{llc}
\hline Indicators & WM & Interpretation \\
\hline Disaster Prevention and Mitigation & 2.86 & Complied \\
1) Conduct of several risk assessment & 2.56 & Complied \\
2) Development and establishment of several early warning systems & 2.32 & Moderately Complied \\
3) Development of tools on risk assessment & 1.88 & Moderately Complied \\
4) Increasing the involvement of communities and LGUs in disaster risk management & 2.29 & Moderately Complied \\
\hline Disaster Preparedness & 1.94 & Moderately Complied \\
1) Conduct of disaster reduction and risk researches & 1.96 & Moderately Complied \\
2) Development and regular review of contingency plans & 2.05 & Moderately Complied \\
3) Development of IEC materials & \\
4) Existence of procedures on disaster communication & 2.66 & Complied \\
\hline Disaster Response & 2.62 & Complied \\
1) Establish institutional mechanism for disaster response operations & \\
2) Improve skills in search, rescue and retrieval operations & 2.26 \\
\hline Disaster Recovery and Rehabilitation & 2.36 & Moderately Complied \\
1) Conduct of post disaster assessments & 2.25 & Moderately Complied \\
2) Integration of DRR into post-disaster recovery and rehabilitation processes & Moderately Complied \\
3) Incorporating DRR elements in planning and management of human settlements & Moderately Complied \\
4) Mainstreaming of DRR in social, economic and human settlements development plan & 2.14 & Moderately Complied \\
\hline Average & 2.34 &
\end{tabular}

more females than males in the survey. Most of the respondents belong to the age bracket 18-30 years old. In terms of members of the household, there are more families with at least 4-6 members. The mentioned information above describes a typical community living in a highly urbanized area.

Table 2 presents the disaster awareness level of the respondents. The highest mean among the indicators belongs to indicator 3. It has a Likert scale interpretation of "aware". However, indicator 5 got the lowest mean with a corresponding Likert interpretation of "moderately aware". On average, the overall mean got a Likert equivalent of "aware". This only shows that in terms of disaster awareness, most of the respondents are aware of the different and types of disaster. They are also familiar with disaster and how does it affect them from time to time.

Table 3 exhibits the level of compliance of the respondents to the different disaster programs. As observed, the highest mean in the table belonged indicator 1 under the disaster prevention and mitigation, which has a corresponding Likert interpretation of "complied". Indicator 4 of disaster prevention and mitigation got the lowest mean, which is equivalent to "moderately complied" on the Likert scale. The overall average mean for the compliance got a score equivalent to "moderately complied". The results imply that the respondents observed that there are still some areas that compliance since they cannot appreciate implementing the programs in the area. It is a vital course of action, in the areas of concern that people living there are knowledgeable of the programs of the government before, during, and after a disaster strikes.

Table 4 shows the t-test for the significant difference in disaster awareness and the level of compliance of respondents on disaster programs when grouped according to sex and location. There is no significant difference in the means scores of males to that of females since the following $t$ values in disaster awareness $t(103)=0.71 ; p=.480$, prevention and mitigation $t(103)=-0.39 ; p=.698$, preparedness $t(103)=-$ $0.27 ; p=.791$, response $t(103)=0.33 ; p=.743$, and recovery and rehabilitation $t(103)=0.38 ; p=.702$ are higher than the alpha significance level of .05. This only means that regardless of the sex, disaster awareness and compliance level is the same among the respondents.

However, on the aspect of the location, there is a significant difference in the scores found in preparedness and recovery and rehabilitation. Those respondents living in higher land have a lower score in preparedness $(\mathrm{M}=1.66$; $\mathrm{SD}=0.59)$ and recovery and rehabilitation $(\mathrm{M}=1.88 ; \mathrm{SD}=0.56)$ than those living in the lower land, $\mathrm{M}=2.41 ; \mathrm{SD}=1.02$ for preparedness and $\mathrm{M}=2.59$ : $\mathrm{SD}=0.98$ for recovery and rehabilitation. The values got, $t(103)=-4.57, p=.000$ for preparedness and $t(103)=-4.50 ; p=.000$ for recovery and rehabilitation yielded a significant result since their $p$ values were higher than the alpha significance of .05 . The rest of the $t$ values like disaster awareness $t(103)=0.821, p=.414$, prevention and mitigation $t(103)=0.951, p=.344$, and response $t(103)=-1.70, p=.092$ are higher than the alpha significance level of .05 . These results show that there are 
Table 4. T-test for Significant Differences on Disaster Awareness and Level of Compliance

\begin{tabular}{|c|c|c|c|c|}
\hline & $n$ & M(SD) & $t$-test & $p$-value \\
\hline \multicolumn{5}{|l|}{ Disaster Awareness } \\
\hline Male & 37 & $2.76(0.46)$ & \multirow{2}{*}{0.71} & \multirow{2}{*}{.480} \\
\hline Female & 68 & $2.68(0.82)$ & & \\
\hline Upper Land & 50 & $2.76(0.43)$ & \multirow{2}{*}{0.821} & \multirow{2}{*}{.414} \\
\hline Lower Land & 55 & $2.66(0.71)$ & & \\
\hline \multicolumn{5}{|c|}{ Disaster Prevention and Mitigation Program } \\
\hline Male & 37 & $2.36(0.82)$ & \multirow{2}{*}{-0.390} & \multirow{2}{*}{.698} \\
\hline Female & 68 & $2.43(0.70)$ & & \\
\hline Upper Land & 50 & $2.48(0.51)$ & \multirow{2}{*}{0.951} & \multirow[b]{2}{*}{.344} \\
\hline Lower Land & 55 & $2.34(0.95)$ & & \\
\hline \multicolumn{5}{|c|}{ Disaster Preparedness Program } \\
\hline Male & 37 & $2.03(0.99)$ & \multirow[b]{2}{*}{-0.270} & \multirow[b]{2}{*}{.791} \\
\hline Female & 68 & $2.08(0.80)$ & & \\
\hline Upper Land & 50 & $1.66(0.59)$ & \multirow{2}{*}{$-4.570^{*}$} & \multirow{2}{*}{.000} \\
\hline Lower Land & 55 & $2.41(1.02)$ & & \\
\hline \multicolumn{5}{|c|}{ Disaster Response Program } \\
\hline Male & 37 & $2.68(0.91)$ & \multirow{2}{*}{0.330} & \multirow{2}{*}{.743} \\
\hline Female & 68 & $2.61(0.90)$ & & \\
\hline Upper Land & 50 & $2.49(0.76)$ & \multirow{2}{*}{-1.720} & \multirow{2}{*}{.092} \\
\hline Lower Land & 55 & $2.77(0.93)$ & & \\
\hline \multicolumn{5}{|c|}{ Disaster Recovery and Rehabilitation Program } \\
\hline Male & 37 & $2.30(0.93)$ & \multirow{2}{*}{0.380} & \multirow{2}{*}{.702} \\
\hline Female & 68 & $2.23(0.80)$ & & \\
\hline Upper Land & 50 & $1.88(0.56)$ & \multirow{2}{*}{$-4.500 *$} & \multirow{2}{*}{.000} \\
\hline Lower Land & 55 & $2.59(0.98)$ & & \\
\hline
\end{tabular}

Table 5. ANOVA for Significant Differences on Disaster Awareness and Level of Compliance grouped according to Age

\begin{tabular}{|c|c|c|c|c|c|}
\hline & & SS & $\mathbf{d F}$ & MS & $F$ value \\
\hline \multirow[t]{3}{*}{ Disaster Awareness } & Between Groups & 1.602 & 3 & 0.354 & \\
\hline & Within & 35.102 & 101 & 0.348 & 1.019 \\
\hline & Total & 36.164 & 104 & & \\
\hline Disaster Prevention and Mitigation & Between Groups & 0.468 & 3 & 0.156 & \\
\hline \multirow[t]{2}{*}{ Program } & Within & 43.582 & 101 & 0.432 & 0.362 \\
\hline & Total & 44.051 & 104 & & \\
\hline \multirow[t]{3}{*}{ Disaster Preparedness Program } & Between Groups & 0.813 & 3 & 0.271 & \\
\hline & Within & 61.234 & 101 & 0.606 & 0.447 \\
\hline & Total & 62.048 & 104 & & \\
\hline \multirow[t]{3}{*}{ Disaster Response Program } & Between Groups & 2.689 & 3 & 0.896 & \\
\hline & Within & 85.501 & 101 & 0.847 & 1.059 \\
\hline & Total & 88.190 & 104 & & \\
\hline Disaster Recovery and & Between Groups & 3.361 & 3 & 1.120 & \\
\hline Rehabilitation Program & Within & 73.387 & 101 & 0.727 & 1.120 \\
\hline
\end{tabular}

$p>.05$

varying ideas and issues of the respondents regarding their opinions on disaster awareness and their compliance in their location.

Table 5 presents the analysis of variance for significant differences in disaster awareness and level of compliance when grouped according to age. As observed, there is no significant difference in the disaster awareness and compliance levels of the respondents when grouped according to age. The following $F$ values for disaster awareness $F(3,101)=1.019, p=.388$; prevention and mitigation $F(3,101)=0.362, p=.781$; preparedness $F(3,101)=0.447, p=.720$; response $F(3,101)=$ $1.059, p=.370$; and recovery and rehabilitation $F(3,101)=$ $1.120, p=.208$ were higher than the alpha significance level of .05 . This means that regardless of the age the awareness and compliance of the respondents for disaster and its programs do not vary that much.
Table 6 shows the analysis of variance for significant differences in disaster awareness and level of compliance when grouped according to the number of family members. As perceived, there is a significant difference in disaster awareness, $F(2,102)=4.490, p=.014$ and prevention and mitigation, $F(2,102)=6.448, p=.002$ since their $F$ values were lower than the alpha significance level of .05. However, preparedness, $F(2,102)=1.339, p=.267$; response $F(2,102)=$ 2.886, $p=.060$; and recovery and rehabilitation $F(2,102)=$ $1.727, p=.183$ showed $F$ values that are higher than the alpha significance level of .05. These results mean that in terms of disaster awareness and prevention and mitigation, the number of family members creates a discrepancy in their opinions and ideas. However, with preparedness, response, and recovery \& rehabilitation, the number of family members does not create variance among their answers of the respondents. 
Table 6. ANOVA for Significant Differences on Disaster Awareness and Level of Compliance grouped according to Number of Family Members

\begin{tabular}{|c|c|c|c|c|c|}
\hline & & SS & $\mathbf{d F}$ & MS & $F$ value \\
\hline \multirow[t]{3}{*}{ Disaster Awareness } & Between Groups & 2.926 & 2 & 1.463 & \\
\hline & Within & 33.238 & 102 & 0.326 & $4.490 *$ \\
\hline & Total & 36.164 & 104 & & \\
\hline Disaster Prevention and Mitigation & Between Groups & 4.945 & 2 & 2.472 & \\
\hline \multirow[t]{2}{*}{ Program } & Within & 39.106 & 102 & 0.383 & $6.448 *$ \\
\hline & Total & 44.051 & 104 & & \\
\hline \multirow[t]{3}{*}{ Disaster Preparedness Program } & Between Groups & 1.587 & 2 & 0.794 & \\
\hline & Within & 60.048 & 102 & 0.593 & 1.339 \\
\hline & Total & 62.048 & 104 & & \\
\hline \multirow[t]{3}{*}{ Disaster Response Program } & Between Groups & 4.723 & 2 & 2.362 & \\
\hline & Within & 83.467 & 102 & 0.818 & 2.886 \\
\hline & Total & 88.190 & 104 & & \\
\hline Disaster Recovery and & Between Groups & 2.514 & 2 & 1.257 & \\
\hline Rehabilitation Program & Within & 74.233 & 102 & 0.728 & 1.727 \\
\hline
\end{tabular}

${ }^{*} \mathrm{p}<.05$

Table 7. Correlation Matrix between Profile of the Respondents, Disaster Awareness and Level of Compliance

\begin{tabular}{|c|c|c|c|c|c|c|c|c|c|}
\hline & 1 & 2 & 3 & 4 & 5 & 6 & 7 & 8 & 9 \\
\hline Location & 1 & & & & & & & & \\
\hline Sex & .015 & 1 & & & & & & & \\
\hline Age & $.196^{*}$ & -.047 & 1 & & & & & & \\
\hline Number of Family Members & .154 & -.023 & -.023 & 1 & & & & & \\
\hline Disaster Awareness & -.081 & -.070 & .030 & .095 & 1 & & & & \\
\hline Prevention and Mitigation Prog. & -.093 & .038 & .058 & -.112 & $.493^{*}$ & 1 & & & \\
\hline Disaster Preparedness Prog. & $.419 *$ & .026 & .169 & -.044 & $.405^{*}$ & $.627 *$ & 1 & & \\
\hline Disaster Response Prog. & .165 & -.032 & .144 & -.166 & $.440^{*}$ & $.587 *$ & $.629 *$ & 1 & \\
\hline Recovery and Rehabilitation Prog. & $.405 *$ & -.308 & .164 & .027 & $.511 *$ & $.484^{*}$ & $.767^{*}$ & $.665 *$ & 1 \\
\hline
\end{tabular}
$* \mathrm{p}<.05$

Table 7 exhibits the correlation matrix between the profile, disaster awareness, and level of compliance of the respondents. As depicted, in terms of profile, the location has a moderate relationship with the level of compliance in disaster preparedness program, $r(103)=.419, p=.000$ and disaster recovery and rehabilitation program $r(103)=.405, p=$ .000 . Disaster awareness is also moderately related to the level of compliance on disaster prevention and mitigation program $r(103)=.493, p=.000$; disaster preparedness program $r(103)=$ $.405, p=.000$; disaster response program $r(103)=.440, p=$ .000 ; and disaster recovery and rehabilitation program $r(103)$ $=.511, p=.000$. This only means that location, disaster awareness, and level of compliance in the disaster programs correlate to some extent from one another. This further confirms that if the respondent has a high response to the disaster, the same also happens to the compliance of that individual.

\section{DISCUSSION}

This study aimed to analyze the awareness and compliance level of individuals regarding disaster and its programs. Based on the proceeding results, we observe varying results from one aspect to another.

Although the respondents in the study are aware of disaster, it is interesting to note that a risk reduction priority in the area got a low result. Concerning this finding, Newnham et al. (2017) reported in their study that only $11 \%$ of the sample reported feeling prepared to respond to a disaster. However, AlQahtany and Abubakar (2020) showed that although almost two-thirds (64.7\%) of their participants are aware of disasters, and $81 \%$ are concerned about disaster risks, less than half (47.3\%) believe that their settlements could be at risk. Varied reasons and factors can contribute to this finding since the urban settlement is a melting pot of different races and beliefs; thus, with disaster awareness, differences can be observed.

For the level of compliance of the respondents to different disaster programs, they described it to be moderately complied. This is so because of the location and the experiences that the respondents might have. The local government unit can also play a role in the concept of implementing disaster programs in the community. Parallel to the finding of the study includes the studies of Aka et al. (2017), Wamsler (2016), Saha and James (2017), and Fayazi et al. (2017) that showed some ideas on how politics and administrative discrepancies can relate to what this study found.

Inferential statistics showed some remarkable results. Although there was, no significant difference found in disaster awareness and level of compliance according to sex, this is against the findings of Rahman (2019) wherein female respondents have a much better risk perception. To support this idea, Mangahas et al., (2018) provided insights on the potential of women in disaster preparedness toward a disasterresilient Filipino community. In terms of location, there is a significant finding involved. The study of Nguyen et al., (2018) supported this claim, wherein they identified challenges in 
integrating disaster risk reduction into the built environment. Individuals' family members proved to be a great challenge since they can be a victim of disaster one day. They can become a survivor or a casualty. As Chan et al., (2016) showed in their study that, public perceptions of disaster in Hong Kong were low, and little preparedness has occurred at the individual or household levels. Newnham et al. (2017) also stipulated that if asked to evacuate in an emergency, $41.9 \%$ of the sample cited significant issues that would prevent them from doing so. However, AlQahtany and Abubakar (2020) also stated that about half of their respondents (54\%) show that they can contribute to reducing disaster risks. Rahman (2019) also showed that younger people have higher knowledge about earthquake preparedness than older people do and lesseducated people are at a higher risk of unpreparedness than more-educated people are.

Statistics also showed significant relationships between disaster awareness and compliance levels on disaster programs. To support this idea, Khairilmizal et al., (2016) specified that significant change in how disaster unfold made some impact on implementing disaster policies. Antronico et al. (2019) showed that there is a communication gap between experts and people since there is a need for local authorities and experts to disseminate the culture of awareness on the risk and to increase the safety level of the citizens. Studies like that of Jigyasu (2016), Sou (2019), Ray (2017), and Leon and March (2016) explored how the community can become resilient and disaster-prepared. Besides, Torabi et al., (2017) and Fayazi et al. (2017) showed that local governments could contribute to building resilience, adapting to climate-related hazards, and post-disaster reconstruction projects. The people and the government need to work hand-in-hand to deal with the everchanging phase of disaster and climate change. There are so many things that need to be done, and it has to be beneficial to each one. We can never tell what is in stored for us tomorrow.

\section{CONCLUSION}

Based on the proceeding results, the researcher concluded that the respondents are aware of the disaster and the level of compliance on disaster programs is moderate. There are also significant differences found in the level of compliance on disaster preparedness and disaster recovery and rehabilitation programs when grouped according to location. We see the same results in disaster awareness and level of compliance with disaster prevention and mitigation programs when grouped according to the number of family members. There is a moderate relationship between the location of the respondents and their disaster awareness. We observe the same between disaster awareness and the level of compliance on disaster programs, which has a moderate relationship.

\section{RECOMMENDATION}

Based on the result of the study, the researcher provided the following recommendations:
1) Strengthen the local disaster risk reduction management group in both the suburb and in the highlands since both locations suffer different disaster;

2) Educate the local community folks in the far-flung areas about disaster risk reduction management.;

3) Create strong and committed DRRM executive committee personnel in the coordination of the local and city DRRM;

4) Provide quarterly seminars and training for local city folks in the barangay levels about disaster awareness and programs provided by the government;

5) Create a group of on-call and trained DRRM volunteers to prepare for rescue and other related matters;

6) Regular monitoring and coordination with the city DRRM for updates and innovations in the search and rescue missions; and

7) Transparency and proper governance of funds before, during, and after the disaster or calamity.

\section{REFERENCES}

Ahmed, I., Gajendran, T., Brewer, G., Maund, K., von Meding, J., \& MacKee, J. (2018). Compliance to building codes for disaster resilience: Bangladesh and Nepal. Procedia Engineering, 212, 986-993. https://doi.org/10.1016/ j.proeng.2018.01.127

Aka, F. T., Buh, G. W., Fantong, W. Y., Zouh, I. T., Djomou, L. B., Gibson, T., ... Hell, J. V. (2017). Disaster prevention, disaster preparedness and local community resilience within the context of disaster risk management in Cameroon. Natural Hazards 86, 57. https://doi.org/10.1007/s11069-016-2674-5

Alarslan, E. (2018). Creating sustainable cities through disaster resilience in Turkey. International Archives of the Photogrammetry, Remote Sensing and Spatial Information Sciences, 42-3/W4, 23-28. https://doi.org/10.5194/isprsarchives-XLII-3-W4-23-2018

AlQahtany, A. M., \& Abubakar, I. R. (2020). Public perception and attitudes to disaster risks in a coastal metropolis of Saudi Arabia. International Journal of Disaster Risk Reduction, 44, 101422. https://doi.org/10.1016/j.ijdrr.2019. 101422

Amaratunga, D., Malalgoda, C. I., \& Keraminiyage, K. (2018). Contextualising mainstreaming of disaster resilience concepts in the construction process. International Journal of Disaster Resilience in the Built Environment, 9(4/5), 348367. https://doi.org/10.1108/IJDRBE-10-2017-0057

Amaratunga, D., Malalgoda, C., Haigh, R., Panda, A., \& Rhayu, H. (2018). Sound practices of disaster risk reduction at local level. Procedia Engineering, 212, 1163-1170. https://doi.org/10.1016/j.proeng.2018.01.150

Antronico, L., Coscarelli, R., De Pascale, F., \& Condino, F. (2019). Social perception of geo-hydrological risk in the context of urban disaster risk reduction: a comparison between experts and population in an area of Southern Italy. Sustainability, 2061. https://doi.org/10.3390/su11072061 
Chan, E. Y., Yue, J., Lee, P., \& Wang, S. S. (2016). Sociodemographic predictors for urban community disaster health risk perception and household based preparedness in a Chinese urban city. PLOS Currents Disasters, 1. https://doi.org/10.1371/currents.dis.287fb7fee6f9f4521af4 $41 \mathrm{a} 236 \mathrm{c} 2 \mathrm{~d} 519$

Chmutina, K., Rose, J., Shrestha, S. D., \& Bhatta, D. (2018). Pathways to raising disaster risk reduction awareness among the informal construction stakeholders: a case of Nepal. Procedia Engineering, 212, 784-791. https://doi.org/10.1016/j.proeng.2018.01.101

Cubelos, C., Kularathhna, A. H. T. S., Valenzuela, V. P. B., Iliopoulus, N., Quiroz, M., Yavar, R., ... Esteban, M. (2019). Understanding community-level flooding awareness in remote coastal towns in Northern Chile through community mapping. Geosciences, 9, 279. https://doi.org/10.3390/geosciences 9070279

Dwirahmadi, F., Rutherford S., Phung, D., \& Chu, C. (2019). Understanding the operational concept of a flood-resilient urban community in Jakarta, Indonesia, from the perspectives of disaster risk reduction, climate change adaptation, and development agencies. International Journal of Environmental Research and Public Health, 16, 3993. https://doi.org/10.3390/ijerph16203993

Fakhruddin, B., Reinen-Hamill, R., \& Robertson, R. (2019). Extent and evaluation of vulnerability for disaster risk reduction of urban Nuku'alofa, Tonga. Progress in Disaster Science, 2, 100017. https://doi.org/10.1016/j.pdisas.2019. 100017

Grady, A., Gersonius, B., \& Makarigakis, A. (2016). Taking stock of decentralized disaster risk reduction in Indonesia. Natural Hazards and Earth System Sciences, 16, 2145-2157. https://doi.org/10.5194/nhess-16-2145-2016

Havko, J., Mitasova, V., Pavlenko, T., Titko, M., \& Kovacova J. (2017). Financing the disaster resilient city in the Slovak Republic. Procedia Engineering, 192, 301-306. https://doi.org/10.1016/j.proeng.2017.06.052

Heidari, M., Eskandary, N., Seifi, B., Jafari, H., \& Pakjouei, S. (2016). Assess features cities resilient to disasters. National Journal of Integrated Research in Medicine, 7(6), 74-78. Retrieved from http://www.nicpd.ac.in/ojs-/index.php/ njirm/article/view/1396

Jigyasu, R. (2016). Reducing disaster risks to urban cultural heritage: global challenges and opportunities. Journal of Heritage Management, 1(1), 59-67. https://doi.org/10.1177/ 2455929616649476

Khairilmizal, S., Hussin, M. F., Hussain, A. R., Jusoh, M. H., Sulaiman, A. A., \& Ainul Husna, K. (2016). Implementation of disaster management policy in Malaysia and its compliance towards international disaster management framework. Information, 19(8A), 3301-3306. Retrieved from https://www.researchgate.net/publication/310446782_Imp lementation_of_disaster_management_policy_in_Malaysia _and_its_compliance_towards_international_disaster_man agement_framework
Kousky, C., \& Shabman, L. (2017). Federal funding for flood risk reduction in the US: pre- or post- disaster? Water Economics and Policy, 3(1), 1771001. https://doi.org/ 10.1142/S2382624X17710011

León, J., \& March, A. (2016). An urban form response to disaster vulnerability: Improving tsunami evacuation in Iquique, Chile. Environment and Planning B: Planning and Design, 43(5), 826-847. https://doi.org/10.1177/ 0265813515597229

Mahmood Fayazi, M., Arefian, F. F., Gharaati, M., Johnson, C., Lizarralde, G., \& Davidson, C. (2017). Managing institutional fragmentation and time compression in postdisaster reconstruction - the case of Bam. International Journal of Disaster Risk Reduction, 21, 340-349. https://doi.org/10.1016/j.ijdrr.2017.01.012

Mangahas, T. L. S., Casimiro, R. R., \& Gabriel, A. G. (2018). Economically challenged women in disaster risk management: toward a resilient Filipino community. Open Journal of Ecology, 8, 42-56. https://doi.org/10.4236/ oje.2018.81004

Mendoza, E. N., Bruno, A. G. T., \& Olpenda, A. S. (2016). Local government unit capacity for disaster risk reduction and management: from disaster to resilience. AES Bioflux, 8 (2), 148-155. Retrieved from https://www.researchgate.net/ publication/298215386_Local_Government_Unit_Capacity _for_Disaster_Risk_Reduction_and_Management_From_Dis aster_to_Resilience

Newnham, E. A., Balsari, S., Lam, R. P. K., Kashyap, S., Pham, P., Chan, E. Y. Y., Patrick K., \& Leaning, J. (2017) Selfefficacy and barriers to disaster evacuation in Hong Kong. International Journal of Public Health, 62, 1051-1058. https://doi.org/10.1007/s00038-017-1036-8

Nguyen, V. N., Ginige, K., \& Greenwood, D. (2018). Challenges in integrating disaster risk reduction into the built environment -the Vietnam context. Procedia Engineering, 212, 316-323. https://doi.org/10.1016/j.proeng.2018.01. 041

Panganiban, C. C. (2019). Citizen satisfaction on the implementation of disaster risk reduction and management in the City of Antipolo. International Journal of Engineering, Science and Computing, 9(3), 20601-20607. Retrieved from https://ijesc.org/upload/54cc6082a54c6f60 3003bbab942e5570.Citizen\%20Satisfaction\%20on\%20the \%20Implementation\%20of\%20Disaster\%20Risk\%20Reduc tion\%20and\%20Management\%20in\%20the\%20City\%20of \%20Antipolo\%20(2).pdf

Rahman, M. (2019), Risk perception and awareness of earthquake: the case of Dhaka. International Journal of Disaster Resilience in the Built Environment, 10(1), 65-82. https://doi.org/10.1108/IJDRBE-04-2018-0020

Ray, B. (2017). Response of a resilient community to natural disasters: the Gorkha earthquake in Nepal, 2015. The Professional Geographer, 69(4), 644-654. https://doi.org/10.1080/00330124.2017.1298452 
Raza, T. (2018). Localizing disaster risk reduction and climate change adaptation in planners' and decision-makers' agenda: technical comprehensive model, Quezon City, Philippines. Procedia Engineering, 212, 1311-1318. https://doi.org/10.1016/j.proeng.2018.01.169

Saha, S. K., \& James, H. (2017). Reasons for non-compliance with cyclone evacuation orders in Bangladesh. International Journal of Disaster Risk Reduction, 21, 196-204. https://doi.org/10.1016/j.ijdrr.2016.12.009

Santos, K. E. S. (2020). Effectiveness of community-based disaster management in Cabanatuan City. International Journal of Social Science and Economic Invention, 6(1), 209211. https://doi.org/10.23958/ijssei/vol06-i01/186

Sardi, M. F., Razak, K. A., \& Bakri, R. Z. (2019). Assessing disaster risk and resilience: a case study in urban flood vulnerable community in Kampung Asahan, Kuala Selangor. International Archives of the Photogrammetry, Remote Sensing and Spatial Information Sciences, 42-4/W16, 603-610. https://doi.org/10.5194/isprs-archives-XLII-4W16-603-2019

Seol-a, K., \& Sang-il, R., (2019). Measures for strengthening performance of disaster and safety management system at local government. International Journal of Human and Disaster, 4(1) 1-7. https://doi.org/10.22471/disaster.2019. 4.1.01

Sou, G. (2019). Sustainable resilience? Disaster recovery and the marginalization of sociocultural needs and concerns. Progress in Development Studies, 19(2), 144-159. https://doi.org/10.1177/1464993418824192
Sudo, N., Mashiro, G., Beppu, S., \& Hakamata R. (2019). A training program to enhance disaster preparedness of group companies in the Tokyo Metropolitan Area. International Journal of Environmental Research and Public Health, 16, 4871. https://doi.org/10.3390/ijerph16234871

Tam, G., Huang, Z., \& Chan, E. Y. Y. (2018). Household preparedness and preferred communication channels in public health emergencies: a cross-sectional survey of residents in an Asian developed urban city. International Journal of Environmental Research and Public Health, 15, 1598. https://doi.org/10.3390/ijerph15081598

Torabi, E., Dedekorkut-Howes, A., \& Howes, M. (2017). Not waving, drowning: can local government policies on climate change adaptation and disaster resilience make a difference? Urban Policy and Research, 35(3), 312-332. https://doi.org/10.1080/08111146.2017.1294538

Valibeigi, M., Feshari, M., Zivari, F., \& Motamedi, A. (2019). How to improve public participation in disaster risk management: a case study of Buein, Zahra, a small city in Iran. Jamba-Journal of Disaster Risk Studies, 11(1), a741. https://doi.org/10.4102/jamba.v11i1.741

Wamsler, C. (2016). From risk governance to city-citizen collaboration: capitalizing on individual adaptation to climate change. Environmental Policy and Governance, 26(3), 184-204. https://doi.org/10.1002/eet.1707 